\title{
Meibomian Gland Dysfunction and Dyslipidemia
}

\author{
Meibomius Bezi Disfonksiyonu ve Dislipidemi \\ Furkan ȘEN 1 (D), Nazmi ZENGiN 2

\begin{abstract}
1 Department of Ophthalmology, Şanlıurfa Mehmet Akif İnan Education and Research Hospital, University of Health Sciences, Şanlıurfa, Turkey

2 Meram School of Medicine, Department of Ophthalmology, Necmettin Erbakan University, Meram/Konya, Turkey
\end{abstract}

\section{Abstract}

Background: Dyslipidemia is a disorder that refers to abnormal value of one or more lipid types in the blood lipid profile. Meibomian gland dysfunction (MGD) is the abnormal condition of meibomian gland secretion which contains lipid components. We aimed to show the relationship between dyslipidemia and the severity of meibomian gland dysfunction.

Materials and Methods: A total of 64 participants who live in Konya were included in the study. Participants were divided into four groups regarded as grade 0 MGD $(n=16)$, grade 1 MGD $(n=16)$, grade 2 MGD $(n=16)$, and grade 3 MGD ( $n=16)$. For each patient, the grade of MGD, blood lipid profile and Marx Line (ML) were evaluated.

Results: The mean age of 48,39 (range 25-65) years, $61 \%(n=39)$ were women and $39 \%(n=25)$ were men. All groups were similar in age $(p=0.666)$ and gender $(p=0.978)$. There was a statistically significant difference in triglyceride (TG) between groups $(p=0,029)$ and there was a significant correlation between increasing level of triglyceride and increasing severity of stage of meibomian gland dysfunction $(r=0,377)$. There was no statistically significant difference in other types of cholesterol between groups $(p>0,05)$. Also, there was a statistically significant difference in width of the Marx Line between groups $(p<0,05)$.

Conclusions: According to our study, dyslipidemia with elevated serum triglyceride and total cholesterol levels, is associated with meibomian gland dysfunction. Meibomian gland dysfunction might give the information about the presence of dyslipidemia.

Key words: Meibomian gland dysfunction; Dyslipidemia; Hypercholesterolemia; Blepharitis; Marx Line.

Öz.

Amaç: Dislipidemi, kan lipit profilinde, bir veya daha fazla lipid türünün anormal değerini ifade eden bir hastalıktır. Meibomius bezi disfonksiyonu (MBD), lipid bileşenlerini içeren Meibomius bezi sekresyonunun anormal durumudur. Bu çalışmamızda dislipidemi ile Meibomius bezi disfonksiyonunun şiddeti arasındaki ilişkiyi göstermeyi amaçladık.

Materyal ve Metod: Konya'da yaşayan toplam 64 katılımcı çalışmaya dahil edildi. Katılımcılar evre 0 MBD $(n=16)$, evre $1 \operatorname{MBD}(n=16)$, evre $2 \operatorname{MBD}(n=16)$ ve evre $3 \operatorname{MBD}(n=16)$ olarak dört gruba ayrıldı. Her hasta için meibomius bezi disfonksiyonu evresi, kan lipid profili ve Marx Çizgisi (MÇ) değerlendirildi.

Bulgular: Hastaların ortalama yaşı 48,39 (25-65 yaş aralığında) yıl olup, \% 61'i ( $n=39)$ kadın, \% 39'u ( $n=$ 25) erkekti. Tüm gruplar yaş $(p=0,666)$ ve cinsiyet açısından benzerdi $(p=0,978)$. Gruplar arasında trigliserit (TG) açısından istatistiksel olarak anlamlı bir fark mevcut olup $(p=0,029)$, artan trigliserit düzeyi ile meibomius bezi disfonksiyonunun şiddeti arasında ise güçlü bir korelasyon vardı ( $r=0,377)$. Gruplar arasında diğer kolesterol türleri açısından istatistiksel olarak anlamlı bir fark yoktu $(p>0,05)$. Ayrıca, gruplar arasında Marx Çizgisi'nin genişliği açısından istatistiksel olarak anlamlı bir fark mevcuttu. $(p<0,05)$.

Sonuç: Çalışmamıza göre, artmış serum total kolesterol ve trigliserit düzeyleri ile birlikte olan dislipidemi meibomius bezi disfonksiyonu ile ilişkilidir. Meibomius bezi disfonksiyonu, dislipidemi mevcudiyeti hakkında bilgi verebilir.

Anahtar kelimeler: Meibomius bezi disfonksiyonu; Dislipidemi; Hiperkolesterolemi; Blefarit; Marx Çizgisi.
Sorumlu Yazar I

Corresponding Author

Furkan Şen MD

Department of Ophthalmology, Şanlıurfa Mehmet Akif İnan

Education and Research Hospital University of Health Sciences,

Esentepe Mh, Ertuğrul Cd 63300 Haliliye/Şanlıurfa/Turkey

e-mail: drfurkansen@gmail.com

Tel : +904143186000

GSM: +90535966 1581

Geliş tarihi / Received: 04.12.2019

Kabul tarihi / Accepted: 02.04.2020

DOI: $10.35440 /$ hutfd. 654903

The study has not been submitted anywhere before.

This study; was produced from Furkan Sen's specialty thesis in Medicine. 


\section{Introduction}

The meibomian glands are tubulo-acinar, holocrine structures that produce meibum secretion that forms the top of the tear layer, prevents evaporation of the aqueous layer and development of dry eye (1). While normal meibomian gland secretion is in lipid structure, chemical studies showed that meibum secretion is composed of triglycerides, diglycerides, polar (8\% phospholipids and glycolipids) and non-polar (77\% wax and sterol esters) lipids, and the ratio of lipid derivatives creates a change in the melting point (2). Meibomian glands are located in a single row along the edge of the lower and upper eyelid (1).

Meibomian gland dysfunction (MGD) is a common disease that can seriously affect the patient's life comfort. Statistical information regarding its prevalence rate $(3.5 \%-77.6 \%)$ (3), risk factors, demographic and geographic distribution, impact on ocular surface, and the patient's quality of life are beginning to emerge. MGD is a chronic disorder characterized by terminal duct obstruction and changes in gland secretion, that may result in clinically apparent inflammation, changes in tear film, symptoms of dry eye, and ocular surface disorder. A number of ophthalmic conditions, aging, dyslipidemia, androgen deficiency, menopause, discoid lupus erythromatosis, parkinson, benign prostatic hyperplasia, systemic diseases and therapies have been identified as risk factors for the development of MGD (4). Current treatment modalities include warm compresses, antibiotic ophthalmic drops, anti-inflammatory ophthalmic drops, and artificial tears. Recently, omega 3 fatty acid supplementation has been shown to assist in the treatment of MGD (5). There is no consensus regarding the definition, clinical evaluation and characteristics of the disease. Knowledge on the pathogenesis and effective treatment of MGD is limited. The disease can be controlled if the risk factors and cause of the disease is illuminated (6). Dyslipidemia is a disorder characterized by elevation of total cholesterol (TC), triglyceride (TG), low-density lipoprotein (LDL) levels and as decrease in high-density lipoprotein (HDL) levels in serum (7). According to epidemiological studies, elevation of LDL and decrease in HDL in serum, with or without other risk factors, play a critical role for cardiovascular diseases and stroke (8). As the melting point of normal meibomian gland secretion is 30 to $34 \mathrm{C}$ and melting point of cholesterol is $46^{\circ} \mathrm{C}$, an increased concentration of cholesterol in meibum would increase the melting point of the meibomian lipid and theoretically increase viscosity that would clog the meibomian gland ducts (7).

The aim of this study is to determine the association of MGD with serum lipid profile. The ability to screen for dyslipidemia might be significant in controlling MGD progression. Also, the presence of MGD might be important in detecting high cholesterol levels.

\section{Materials and Methods}

Following the tenets of the Declaration of Helsinki, all patients were seen in Necmettin Erbakan University Meram Medical Faculty opthalmology clinic, provided informed consent after approval from the ethical committee of the institution (Ethical Committee of Necmettin Erbakan University Meram Medical Faculty, Date: 18/09/2015, No:2015/326). The study included all patients from September 2015 until March 2016 based on symptomatology and slit lamp examination. All patients who were known to have any ocular and orbital pathology, concomitant topical medications (including corticosteroids in the 4 weeks before the study) especially for glaucoma, ophthalmological disease underwent surgery, corneal arcus (also were excluded because this clinical sign is a potential marker of elevated blood cholesterol), pregnancy, systemic disease and hyperlipidemia on any lipid-lowering medication including omega 3 were excluded from the study. All patients were evaluated by the author.

Consecutive patients presenting with symptoms suggestive of dry eye were evaluated. A detailed history using a dry eye questionnaire was taken. Thorough clinical examination was performed to confirm the diagnosis of dry eye and for the probable etiology.

The diagnosis and grading of the meibomian gland dysfunction (MGD) was done by slit lamp biomicroscopic evaluation of meibum expressivity by digital pressure on the middle third of the lower eyelid and evaluation of the expressed material, a method known to have $86 \%$ sensitivity and $73 \%$ specificity (9). Grade 0 is when the patient has a patent meibomian gland orifices expressing clear fluid on mild digital pressure. Grade 1 was defined as the presence of ductal plugging and the expression of clear fluid when firm digital pressure was applied to the glands. Grade 2 was defined as the presence of ductal plugging and the expression of cloudy fluid when firm digital pressure was applied to the glands. Grade 3 was defined as ductal plugging and the presence of inspissated material, the lack of expression when firm digital pressure was applied to the glands, or glandular loss. All patients were tested for fasting serum lipid profiles at the time of diagnosis. The reference ranges of the cholesterol components in our laboratory were; total cholesterol (TC) (0-200 mg/dl), triglyceride (TG) (0-150 mg/dl), low-density lipoprotein (LDL) (100-130 mg/dl) and high-density lipoprotein (HDL) (40-60 $\mathrm{mg} / \mathrm{dl})$. Dyslipidemia was diagnosed if the patient had fasting serum TC $>200 \mathrm{mg} / \mathrm{dl}$, TG $>200 \mathrm{mg} / \mathrm{dl}, \mathrm{LDL}>130$ $\mathrm{mg} / \mathrm{dl}$, and $\mathrm{HDL}<40 \mathrm{mg} / \mathrm{dl}$.

Once patients were selected, baseline assessment included:

- Grading of the MGD

- Assessing the staining of Marx's Line (ML) with lissamine green dye $(\mathrm{mm})$ : Lissamine Green dye strips were used to stain the marginal zone of the palpebral conjunctiva, the 
width of the Lissamine Green-stained ML was measured of the everted upper eyelid with a Schirmer's test paper (10). Statistical analysis was performed with SPSS software version 21.0 (SPSS, Inc., Chicago, IL, U.S.A.). The Shapiro Wilk's test was used to test normality of distribution. Categorical variables were presented in number and percentage (\%) and continuous variables were presented as mean \pm SD and median. Qualitative variables were correlated using Chi-square test. The relationship between the quantitative variables, which have more than two subgroups, was evaluated with the variance analysis in the normally distributed variables and was evaluated with the Kruskal-Wallis test in the non-normally distributed variables. Kruskall-Wallis and Spearman's Correlation coeffiecient tests were performed to identify associations among variables. A $p$ value of $<0.05$ was considered significant.

\section{Results}

A total of 64 patients were included with a mean age of 48,39 (range 25-65) years, $61 \%(n=39)$ were women and $39 \%(n=25)$ were men. The grade 0 MGD group consisted of 16 patients ( 10 women, 6 men; mean age, $45,25 \pm 12,47$ years), grade 1 MGD group consisted of 16 subjects (10 women, 6 men; mean age, 48,69 $\pm 10,17$ years), grade 2 MGD group consisted of 16 subjects (10 women, 6 men; mean age, 49,81 $\pm 11,37$ years), grade 3 MGD group consisted of 16 subjects ( 9 women, 7 men; mean age, 49,81 $\pm 11,37$ years); statistical analysis showed that groups were well matched for sex and age. There was no significant difference between the groups in terms of age $(p=0,666)$ and gender $(p=0,978)$.

Table 1. Association of lipid profile with severity of meibomian gland dysfunction cases

\begin{tabular}{clllll}
\hline & $\begin{array}{l}\text { Grade 0 } \\
\text { MBD } \\
\text { mean } \pm \text { sd }\end{array}$ & $\begin{array}{l}\text { Grade 1 } \\
\text { MBD } \\
\text { mean } \pm \text { sd }\end{array}$ & $\begin{array}{l}\text { Grade 2 } \\
\text { MBD } \\
\text { mean } \pm \text { sd }\end{array}$ & $\begin{array}{l}\text { Grade 3 } \\
\text { MBD } \\
\text { mean } \pm \text { sd }\end{array}$ & P \\
\hline TC & $196,0 \pm 43,83$ & $174,0 \pm 41,35$ & $194,25 \pm 30,22$ & $208,75 \pm 31,15$ & $\mathbf{0 , 0 4 7 * *}$ \\
TG & $94,81 \pm 43,06$ & $105,69 \pm 49,05$ & $124,81 \pm 53,19$ & $130,37 \pm 31,02$ & $\mathbf{0 , 0 2 9 * *}$ \\
HDL & $54,37 \pm 14,79$ & $48,87 \pm 8,88$ & $53,06 \pm 12,10$ & $49,37 \pm 11,72$ & 0,507 \\
LDL & $122,62 \pm 34,72$ & $103,75 \pm 34,18$ & $116,12 \pm 27,57$ & $133,06 \pm 27,31$ & 0,075 \\
\hline $\begin{array}{l}\text { HDL: high-density lipoprotein; LDL:low-density lipoprotein; } \\
\text { MGD:meibomian gland dysfunction; }\end{array}$ & & & \\
sd= standard deviation; TC=total cholesterol; TG= triglycerides; & &
\end{tabular}

As seen in Figure 1 and Table 1, mean levels of total cholesterol (TC) in groups were 196,0 $\pm 43,83,174,0 \pm 41,35$, $194,25 \pm 30,22$ and $208,75 \pm 31,15 \mathrm{mg} / \mathrm{dL}$, respectively, in grade 0 MGD, grade 1 MGD, grade 2 MGD and grade 3 MGD groups; there was no statistically significant difference in TC between groups $(p=0,047)$ and there was a fairly correlation between increasing level of TC and increasing severity of stage of MGD $(r=0,225)$. Mean levels of triglyceride (TG) in groups were 94,81 $\pm 43,06,105,69$ $\pm 49,05,124,81 \pm 53,19$ and $130,37 \pm 31,02 \mathrm{mg} / \mathrm{dL}$, respectively, in grade 0 MGD, grade 1 MGD, grade 2 MGD and grade 3 MGD groups; there was a statistically significant difference in TG between groups $(p=0,029)$ and there was a significant correlation between increasing level of TG and increasing severity of stage of MGD $(r=0,377)$. Mean levels of low-density lipoprotein (LDL) in groups were $122,62 \pm 34,72,103,75 \pm 34,18,116,12 \pm 27,57$ and $133,06 \pm 27,31 \mathrm{mg} / \mathrm{dL}$, respectively, in grade $0 \mathrm{MGD}$, grade 1 MGD, grade 2 MGD and grade 3 MGD groups; there was no significant difference in LDL between groups $(p=0,075)$ and there was no significant correlation between increasing level of LDL and increasing severity of stage of MGD $(r=0,174)$. Mean levels of high-density lipoprotein (HDL) in groups were 54,37 $\pm 14,79,48,87 \pm 8,88,53,06$ $\pm 12,10$ and $49,37 \pm 11,72 \mathrm{mg} / \mathrm{dL}$, respectively, in grade 0 MGD, grade 1 MGD, grade 2 MGD and grade 3 MGD groups; there was no significant difference in $\mathrm{HDL}$ between groups $(p=0,507)$ and there was no significant correlation between decreasing level of $\mathrm{HDL}$ and increasing severity of stage of MGD $(r<0.01)$.

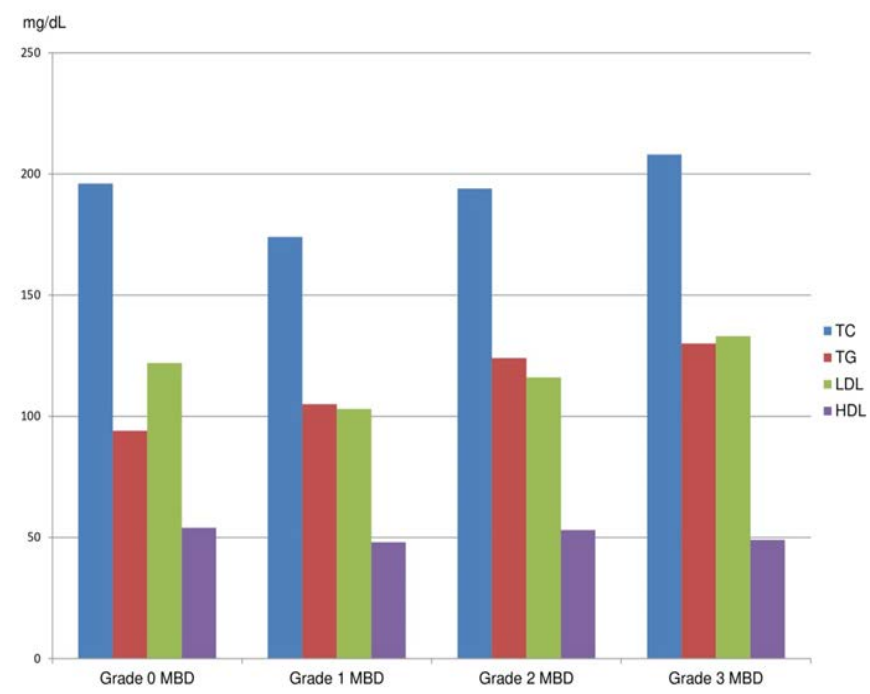

Figure 1. The mean levels of cholesterol in groups

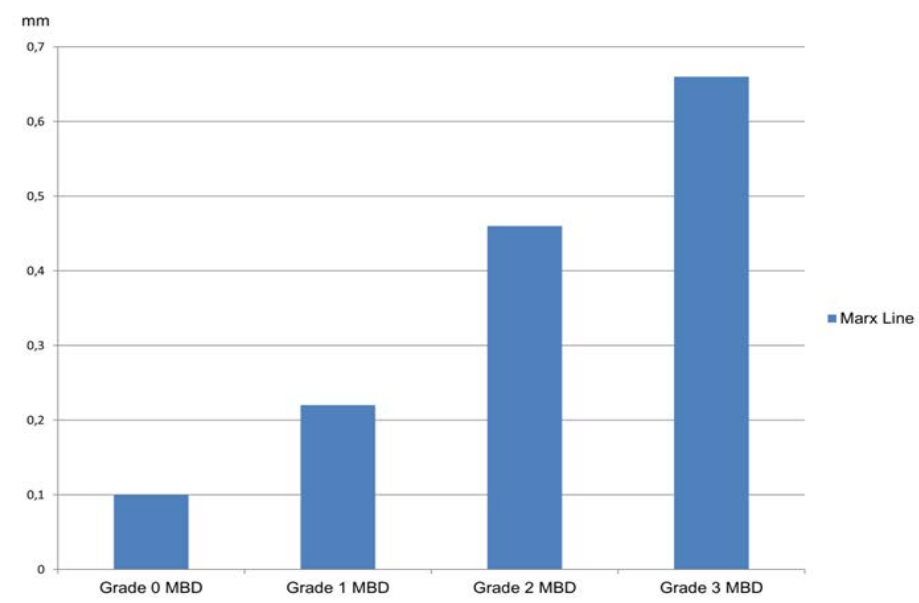

Figure 2. The mean values of width of the Marx's Line in groups 


\section{Discussion}

Meibomian gland dysfunction (MGD), is a chronic disease that causes ocular irritation and has not been adequately reported. Some epidemiological studies have reported that the prevalence of MGD, which varies depending on characteristic of population, has risen to $70 \%$ (11). The cause of MGD is partially understood, but changes in the meibum content and obstruction of the meibomian gland ducts are thought to be important factors. Studies show that components and cholesterol ratios of meibum in MGD patients are different from control patients (12). Cholesterol esters were present in the meibum of MGD patients, but not significantly in control patients. Increased cholesterol is postulated to play an important role in the pathogenesis of MGD in recent research (4,13-15). Organic substances, which with content of saturated fats and large side chains, have higher melting point (16). This theory can explain why the melting point of normal meibomian gland secretion is 30 to 34 Celsius while cholesterol, with its structural differences, has a typical melting point of 46 degrees Celsius. Theoretically, If meibum has a high cholesterol content, therefore its melting point would increase and meibum would be more viscous thus blocking meibomian gland ducts (7).

Dyslipidemia refers to abnormal value of one or more lipid types of the blood lipid profile. According to epidemiological studies, elevation of low-density lipoprotein (LDL) and decrease in high-density lipoprotein (HDL) in serum, with or without other risk factors, play a critical role for cardiovascular diseases and stroke (17).

Aging and gender play an active role in the change of blood lipid profile values because total cholesterol levels have been shown to increase with aging $(18,19)$. We mitigated a selection bias by choosing groups which were similar to each other in terms of gender, age, and especially socioeconomic standing which is believed to reflect greater similarity in dietary intake and overall health (20).

This study concluded that dyslipidemia, associated with increased triglycerides (TG) and total cholesterol (TC) levels, was associated with MGD. However, we could not detect any statistically significant correlation between the MGD and other cholesterol types. This is consistent with the findings obtained in the studies conducted by Pinna et al. (15), Guliani et al. (19) and Briach et al. (21). Furthermore, they found LDL levels associated with MGD, however in our study there was no significant correlation between LDL levels and MGD severity.

Although Dao et al. (14) and Pinna et al. (15) also detected a higher prevalence of dyslipidemia among patients with MGD, this was in relation mainly to total cholesterol to be similar to our study. But, they found a relationship between MGD and high HDL levels and concluded that dyslipidemia, which increases HDL levels, may be a risk factor for the development of MGD. However, elevated
HDL has not yet been associated with any pathological condition. Furthermore, elevated total cholesterol levels in their study might have been affected by elevated HDL levels. In contrast, Guliani et al. (19) detected a relationship between MGD and low HDL levels. Bukhari et al. (4) detected high TG levels with MGD patients to be similar to our study and high LDL levels to be different from our study.

Yamaguchi et al. postulated that there was a significant correlation between width of the Marx's Line (ML) and MGD severity in their study similarly to our study (22). The assessing of width of the ML may be a simple and important marker in the assessment of MGD severity in practical use.

In other studies $(4,14,15,19,21)$, the MGD groups and control groups were not similar in number of patient, age and gender, but were similar in our study. It should be noted that if the MGD is affected by the levels of serum cholesterol, investigating the correlation between increasing levels of serum cholesterol and increasing severity of stage of MGD might be more valuable than evaluating the association between meibomian gland dysfunction cases and control group. Because, investigating the association between patient and control groups may not adequately indicate the correlation between MGD severity and dyslipidemia. In addition, to the best of our knowledge, this is the first article which purposed to study the association between dyslipidemia and MGD which defined by the ML. In our study, it was concluded that the severity of MGD was particularly related to TG levels. Therefore, according to our study, the presence of MGD may be an indicator for presence of hypertriglyceridemia and treatment of hypertriglyceridemia might be helpful to control of the MGD.

\section{Study Limitations}

Our study is limited by the fact that the relatively small sample size that was due to the strict exclude criteria used to avoid possible confounders. The second limitation is that the study was conducted only from the Turkish population. Last, but not least, the pathogenesis of MGD is not clearly understood and multifactorial in addition to our hypothesis.

\section{Conclusion}

This study concluded that dyslipidemia with increased triglyceride (TG) and total cholesterol (TC) levels, was associated with MGD. Therefore, it was suggested that monitoring of dyslipidemia may contribute to the treatment of MGD and treatment of dyslipidemia might be helpful in the progress of MGD. The evaluation of ML may be helpful in the examination of MGD severity. Furthermore, it is exciting to consider dyslipidemia in the presence of MGD. Moreover, If the relationship between MGD and dyslipidemia is confirmed by larger studies, lipid-lowering therapies may be used to control the MGD. 


\section{Acknowledgements}

The author would like to thank Alparslan Ali İzki, MD for statistical assistance.

\section{Financial support and sponsorship}

Nil.

\section{Conflicts of interest}

There are no conflicts of interest.

\section{Ethical approval:}

The study was approved by the Ethical Committee of Necmettin Erbakan University Meram Medical Faculty, Date: 18/09/2015, No:2015/326

\section{References}

1. Bron AJ, Benjamin L, Snibson R. Meibomian gland disease: classification and grading of lid changes. Eye 1991;5:395-411.

2. Nicolaides N, Kaitaranta JK, Rowdah TN, Macy JI, Boswell FM, Smith RE. Meibomian gland studies: comparison of steer and human lipids. Invest Ophthalmol Vis Sci 1981;20:522-36.

3. Schein OD, Muñoz B, Tielsch JM, et al. Prevalence of dry eye among the elderly. Am J Ophthalmol 1997;124:723-8.

4. Amal A. Bukhari, m.d. et al. Associations Between the Grade of Meibomian Gland Dysfunction and Dyslipidemia. Ophthal Plast Reconstr Surg 2013;29:101-103

5. Macsai M. The role of omega-3 dietary supplementation in blepharitis and meibomian gland dysfunction. Trans Am Ophthalmol Soc 2008;106:336 -356

6. Nelson JD, Shimazaki J, Benitez-del-Castillo JM, et al. The international workshop on meibomian gland dysfunction: report of the definition and classification subcommittee. Invest Ophthalmol Vis Sci 2011;52:1930-7.

7. Butovich IA, Millar TJ, Ham BM. Understanding and analyzing meibomian lipids. Curr Eye Res 2008;33:405-20.

8. Wilson PW, D'Agostino RB, Levy D, et al. Prediction of coronary heart disease using risk factor categories. Circulation 1998;97:1837.

9. Tomlinson A, Bron AJ, Korb DR, et al. The international workshop on meibomian gland dysfunction: report of the diagnosis subcommittee. Invest Ophthalmol Vis Sci 2011;52:2006-49.

10. Hughes C, Hamilton L, Doughty MJ, PhD, FAAO. A Quantitative Assessment of the Location and Width of Marx's Line Along the Marginal Zone of the Human Eyelid. Optom Vis Sci 2003;80:564-72.

11. Rege A, Kulkarni V, Puthran N, Khandgave T. A clinical study of subtype-based prevalence of dry eye. J Clin Diagn Res. 2013;7:2207210.

12. Shine WE, McCulley JP. Role of wax ester fatty alcohols in chronic blepharitis. Investig Ophthalmol Vis Sci 1993;34:3515-3521.

13. Shine WE, McCulley JP. Polar lipids in human meibomian gland secretions. Curr Eye Res 2009;26:89-94.

14. Dao AH, Spindle JD, Harp BA et al. Association of dyslipidemia in moderate to severe meibomian gland dysfunction. Am J Ophthalmol 2010;150:371-375.

15. Pinna A, Blasetti F, Zinellu A, Carru C, Solinas G. Meibomian gland dysfunction and hypercholesterolemia. Ophthalmology 2013;120(12):2385-2389.

16. Bettelheim FA, Brown WH, Campbell MK, Farrell SO, Torres OJ. Introduction to general, organic and biochemistry. Available from: www.valorebooks.com/textbooks/introductiontogeneralorganicandbioc hemistry10ththedition/9781133105084\#default=buy\&utm_source=Bing\&utm_medium=cpc\&utm_campaign=BingFTP\&date $=06 / 1 \overline{7} / 15$.

17. Muntner P, Colantonio LD, Cushman M, Goff DC Jr, Howard G, Howard VJ et al. Validation of the atherosclerotic cardiovascular disease Pooled Cohort risk equations. JAMA 2014;311(14):1406-1415.

18. Hockley T, Gemmill M. European Cholesterol Guidelines Report.
Hampshire, England: Policy Analysis Centre; 2007. (Accessed March 19, 2013). Available from: www.policy-centre.com/downloads/European-Cholesterol- Guidelines07.pdf.

19. Guliani BP, Bhalla A, Naik MP. Association of the severity of meibomian gland dysfunction with dyslipidemia in Indian population. Indian J Ophthalmol. 2018; 66(10): 1411-1416.

20. Sedgwick P. Confounding in case control studies. BMJ 2010;341:c5136.

21. S. Braich . Mary K. Howard . Jorawer S. Singh Dyslipidemia and its association with meibomian gland dysfunction. International Ophthalmology Augus 2016,36,(4),469-476.

22. Yamaguchi M, Kutsuna M, UNO T, Zheng X, Kodama T, Ohashi Y. Marx Line: Fluorescein Staining Line on the Inner Lid as Indicator of Meibomian Gland Function. Am J Ophthalmol 2006;141:669-675. 